\title{
Suurten ikäluokkien työllistämisongelma
}

\author{
Valtiot, tri TERHO PULKKINEN
}

Työmarkkinatutkimustoimisto

Korkean työllisyyden säilyttäminen on vaatinut yhteiskunnaltamme miltei koko kuluneen vuosikymmenen ajan aivan erityisiä ponnistuksia, ja varsin yleisesti on vallalla käsitys, että 1960-luvun työllisyysongelma on vieläkin vaikeampi, ellei ryhdytä riittävän tehokkaisiin toimenpiteisiin taloudellisen kasvun edistämiseksi ja uusien työtilaisuuksien luomiseksi. Ne tehtävät, joihin on käytävä käsiksi, ovat entistä vaativampia useastakin syystä.

Ensiksi menneen vuosikymmenen perinnöksi jättämä työttömyys on kyettävä poistamaan. Toiseksi työvoiman lisäys on poikkeuksellisen suuri 1960-luvulla ja erityisesti sen alkupuolella, jolloin vuosina 1945-50 syntyneet ns. suuret ikäluokat alkavat tulla työmarkkinoille. Yhteiskunta tuntee olevansa erityisesti vastuussa nuorista työntekijöistä, heidän kouluttamisestaan tuotantoelämän palvelukseen ja heidän sijoittamisestaan työmarkkinoille mahdollisimman tarkoituksenmukaisesti. Nuoren työvoiman työllisyyttä ei kuitenkaan voida ottaa esille erillisenä kysymyksenä, vaan ongelmaa on pohdittava koko työvoimaa ja sen työllistämismahdollisuuksia silmällä pitäen. Nuorien vasta ensimmäistä työpaikkaansa etsivien työntekijäin sijoittuminen työmarkkinoille on nimittäin riippuvainen lähinnä yleisestä työllisyystilanteesta. Kolmanneksi yhteiskunnassa jatkuvasti tapahtuvien rakennusmuutoksien ansiosta maaja metsätalouden piiristä vapautuu työvoimaa, joka hakeutuu toisiin elinkeinohaaroihin.

\section{Työttömyys}

On myönnettävä, että joitakin poikkeuksellisen edullisia vuosia lukuunottamatta työttömyyskortistoihin merkittyjen henkilöiden määrä on viime aikoina etenkin talvisin kohonnut varsin huomattaviin lukuihin. Työtilaisuuksia on jouduttu lisäämään vuosi vuodelta kasvavilla julkisin varoin rahoitetuilla työttömyys- ja työllisyystöillä. Tällaisen työohjelman ansiosta kortistoihin merkityistä on yleensä vain noin kymmenesosa ollut todella työttömänä. Muutenkaan ei ole kiinnitettävä liian suurta huomiota työttömyyskortistoihin merkittyjen työntekijäin kokonaismäärään, sillä työttömyys- ja työllisyystöissä olevien työntekijäin lukumäärä on suurelta osalta budjettiteknillinen seikka. Näiden töiden joukossa on nimittäin lukuisasti täysin normaaleja valtion ja kuntien työkohteita. Tämän seurauksena julkisen sektorin vapaissa töissä olevien työntekijäin määrä on pienempi kuin välttämättömien ja kiireellisten töiden ohjelma edellyttäisi ja työllisyysvaroin rahoitetuissa töissä olevien määrä on vastaavasti kasvanut. Kun työttömyyden määrää mitataan ns. työvoimatutkimuksen avulla (vrt. tämä vuosikirja s. 15-28), saadaan lukuja, jotka ovat vertailukelpoisia eräiden muiden maiden vastaaviin lukuihin, ja voidaan todeta, ettei meidän työttömyytemme kansainvälisen mittapuun mukaan ole suinkaan ollut ennätyksellistä. Oman ilmoituksensa mukaan vähintään viikon työttöminä olleita henkilöitä (prosenttina työvoimasta) oli meillä Suomessa, Kanadassa, USA:ssa ja Ruotsissa eri ajankohtina seuraavasti: 


\begin{tabular}{|c|c|c|c|c|}
\hline & II 1959 & V 1959 & VIII 1959 & XI 195 \\
\hline Suomi & 3.4 & 1.7 & 2.0 & 1.8 \\
\hline Kanada & 9.4 & 5.7 & 4.0 & 5.1 \\
\hline USA & 7.0 & 4.9 & 4.7 & 5.3 \\
\hline Ruotsi & .. & 3.5 & & \\
\hline
\end{tabular}

Laajan julkisin varoin rahoitetun työohjelman ansiosta on maassamme kyetty kuluneina laskusuhdannevuosinakin säilyttämään verraten korkea työllisyys eikä työvoimareservimme ilmeisesti ole niin jättiläismäinen kuin usein on esitetty eikä se tulevaisuutta ajatellen anna aihetta heittäytyä toivottomuuteen.

Erityisen taloudellisina laskusuhdannevuosina työttömiksi ilmoittautuu runsaasti myös nuoria työntekijöitä, joskin työttömyys yleensä näyttää meillä viime vuosina olleen pikemminkin vanhojen kuin nuorten ongelma. Syksyllä 1959 suoritettu tiedustelu osoitti, että työttömyyskortistoihin merkittyjen miesten ja koko miespuolisen väestön ikäjakautumat olivat pääpiirteissään toistensa kaltaiset. Kuitenkin voitiin panna merkille, että maalaiskunnissa työttömiksi luetteloitujen nuorukaisten osuus oli huomattavasti suurempi ja väestökeskuksissa pienempi kuin koko väestön ikärakenne edellytti. Nuorimpiin ikäluokkiin kuuluvien miesten osuus prosenttina kaikista työttömyyskortistoihin merkityistä miehistä oli seuraava (suluissa vastaavan ikäluokan osuus kaikista 16 vuotta vanhemmista miehistä):

$\begin{array}{ccc}\text { Ikävuotta } & \text { Kaupungit ja kauppalat } & \text { Maalaiskunnat } \\ \% & \% \\ 17-19 & 5.0(6.5) & 9.8 \quad(7.8) \\ 20-24 & 8.2(10.8) & 14.0(12.6)\end{array}$

Koko valtakunnassa 17-19-vuotiaita nuorukaisia oli $8.4 \%$ kaikista kortistoihin merkityistä miehistä eli hieman enemmän kuin kaikkien tuohon ikäryhmään kuuluvien miesten osuus $(7.3 \%)$ koko 16 vuotta vanhemmasta miespuolisesta väestöstä.

Työttömiksi ilmoittautuneiden nuorten suhteellinen enemmyys maaseudulla on osoituksena siitä, että täällä nuoret joutuvat hakeutumaan työmarkkinoille aikaisemmin kuin väestökeskuksissa, joissa voidaan käyttää enemmän aikaa opiskeluun ja ammattitaidon hankkimiseen.

Työnvälityksenkin kautta työtä hakeneiden nuorten määrä on viime vuosina ollut varsin vähäinen. Työnvälitystoiminnan aktiivisuuden lisääntyessä ja työllisyystilanteen vaikeutuessa on tosin myös nuorten (alle 18-vuotiaiden) työnhakijain absoluuttinen määrä huomattavasti kasvanut 1950-luvun jälkipuoliskolla, mutta ei kuitenkaan niin paljon kuin kaikkien työnhakijain määrä. Vuonna 1955 nuoria

työnhakijoita oli n. 650 keskimäärin kuukautta kohden eli 4.4 \% kaikista työnhakijoista. Vuonna 1958 heidän lukumääränsä oli lähes kolminkertaistunut, mutta suhteellinen osuutensa alentunut $3.3 \%$ :iin.

Koulujen päättymisen vaikutus nuorten työnhakuun näkyy varsin selvästi työnvälitysnumeroissa. Alle 18-vuotiaiden osuus kaikista työnhakijoista oli keskimäärin vuosina 1955-1959 kuukausittain seuraava:

Kuukausi

Tammikuu

Helmikuu

Maaliskuu

Huhtikuu

Toukokuu

Kesäkuu

Heinäkuu

Elokuu

Syyskuu

Lokakuu

Marraskuu

Joulukuu
Alle 18-vuotiaita \% kaikista työnhakijoista

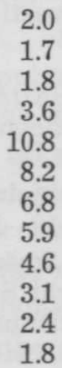


Keväällä osa nuorista työnhakijoista etsii työtä vain siksi ajaksi, jolloin kouluissa on lomakausi, kun taas koulunsa päättäneet pyrkivät tällöin lopullisesti sijoittumaan työmarkkinoille. Kevät lieneekin se aika, jolloin suurin osa uudesta ikäluokasta tulee työvoimaan.

Edellä olevalla on haluttu osoittaa, että 1950-luvulla mainittavaa nuorisotyöttömyyttä on esiintynyt meillä korkeintaan maaseudulla, jossa koulutusmahdollisuuksien puute on pakottanut lukuisat nuoret, alle 20-vuotiaat henkilöt hakeutumaan ansiotyöhön kouluttamattomina ja ammattitaidottomina, josta on ollut seurauksena työttömyysriskin kasvaminen.

Useissa eri tutkimuksissa on käynyt selville, että nuoret työntekijät ovat erityisen arkoja työttömyydelle vain siinä vaiheessa, kun he etsivät ensimmäisiä työpaikkojaan, jolloin he joutuvat usein vaihtamaan työalaa ja työnantajaa. Kerran työmarkkinoille sijoituttuaan he ovat kuitenkin yleensä varsin hyvin kilpailukykyisiä. Työttömyysjakson jälkeen he voivat jopa paremminkin kuin vanhat työntekijät sijoittua uudelleen työhön. Tämä kaikki pitää kuitenkin paikkansa vain siinä tapauksessa, että nuoret ovat saaneet riittävän ammattikoulutuksen.

\section{Työvoiman tarjonnan kasvu}

Eniten huolestumista työvoiman tulevasta kehityksestä on herättänyt se, että työvoiman tarjonta lisääntyy lähivuosina nopeammin kuin mihin olemme viime vuosikymmeninä tottuneet. Työikäinen (15-64-vuotias) väestö kasvaa nimittäin keskimäärin vuodessa viisivuotiskausittain seuraavasti: 1

1 Tor Hartman. Väestönkehityksen ennuste vuoteen 1975 saakka. Tilastokatsauksia 1959, 4.

2 Talousohjelmakomitean mietintö 1960 . Moniste, s. 19-20.

3 Aarno Strömmer. Väestönkehitys ja työvoimavarat Suomessa vuosina 1950-70. Valtakunnansuunnittelutoimiston julkaisusarja A: 5. Helsinki 1959.
Lisäys tuhatta henkilöä

$\begin{array}{ll}1946-50 & 11.2 \\ 1951-55 & 21.0 \\ 1956-60 & 26.1 \\ 1961-65 & 46.9 \\ 1966-70 & 30.7\end{array}$

Vuosina 1961-65 lisäys on täten lähes kaksi kertaa suurempi kuin vuosina 1956-60. Prosentteina laskien työikäisen väestön kasvu oli 1950-luvun jälkipuoliskolla $3.9 \%$, mutta 5-vuotiskaudella 1961-65 peräti $6.5 \%$ eli enemmän kuin koskaan aikaisemmin vuoden 1926 jälkeen.

Yleisenä piirteenä työikäisen väestön kehityksessä on lisäksi pantava merkille nuorimpien ikäluokkien (15-24-vuotiaiden) voimakas lisääntyminen 1960-luvun loppupuolelle saakka. Vuodesta 1960 vuoteen 1970 15-24-vuotias väestö lisääntyy ennusteen mukaan nimittäin 224000 henkeä, eli keskimäärin $2.9 \%$ vuotta kohden, kun taas koko työikäisen väestön kasvu on 388000 henkeä eli vain $1.3 \%$ vuotta kohden.

Vaikka työikäisen väestön todennäköinen kehitys tiedetäänkin, on työvoiman määrän ennustaminen varsin vaikea tehtävä ja tulokset jäävät usein otaksuman luontoisiksi. Työvoiman määrä on nimittäin riippuvainen ns. työintensiteettiluvusta, jonka on havaittu jatkuvasti muuttuvan siten, että se näyttää yleensä laskevan elintason kohotessa. Alenemista on tapahtunut lähinnä nuorimpien ja vanhimpien ikäluokkien sekä naimisissa olevien naisten osalta koulutusajan pitenemisen, eläkkeitten yleistymisen yms. seikkojen vuoksi. Käyttäen apuna muiden maiden vastaavaa kehitystä voidaan yrittää arvioida työintensiteetin aleneminen meillä sanotuissa ikäluokissa vuosina 1950-70.2 Toinen mahdollisuus on olettaa työintensiteetin pysyvän aina vuoteen 1970 saakka samana kuin vuonna $1950 .^{3}$

Jos työintensiteettilukuja varovasti alennetaan nuorimmissa ja vanhimmissa ikäluokissa, päädytään siihen, että työvoiman määrä lisääntyy vuosina 1959-70 noin 303000 henkilöä. Vuotuinen lisäys on suurin 1960-luvun ensi vuosina, jolloin 
se ylittää 30000 . Koulutuksen yleistyminen ja koulutusajan piteneminen saattaa kuitenkin hajoittaa tämän huipun odotettua useamman vuoden osalle. Mainittakoon, että vuosina 1951-57 työvoima kasvoi vain n. 13000 henkeä vuodessa, joten tuleva vuosilisäys on tähän verrattuna jopa yli kaksinkertainen.

Jos taas lähdetään siitä, että työintensiteetti ei lainkaan alene vuoteen 1970 mennessä, saadaan työvoiman lisäykseksi vuosina $1959-70$ n. 380000 henkilöä, jolloin vuotuinen lisäys 1960-luvun alussa nousisi jopa 40000 työntekijään.

\section{Elinkeinorakenteen muuttuminen}

Tulevaa työvoiman tarjontaa ajatellen on vielä otettava huomioon, että meillä on kaksi elinkeinohaaraa, maatalous ja metsätalous, joissa työvoiman määrän kehityssuunta on aleneva. Vuosittain näistä siirtyy runsaasti työntekijöitä muiden maaseudun elinkeinojen kautta väestökeskuksiin taajamaelinkeinoihin. Tämä ilmiö liittyy yhteiskunnan taloudelliseen kehitykseen ja on työllisyysongelmamme keskeisimpiä kysymyksiä. Vuonna 1920 sai vielä noin $75 \%$ työvoimastamme toimeentulonsa maa- ja metsätaloudesta, mutta vuonna 1950 vain $47 \%$ ja tällä hetkellä arviolta enää $37 \%$. Maatalouden työvoiman vähenemisen viimeaikaista kehitystä ja siihen liittyviä ilmiöitä on Heikinheimo lähemmin käsitellyt tässä vuosikirjassa (s. 19-26). Tulkoon nyt vain todetuksi, että työvoiman siirtyminen maa- ja metsätaloudesta muihin elinkeinoihin tapahtunee 1960-luvulla ainakin vähentymättömällä nopeudella (1-1 1/2 \% vuodessa). Tämä merkitsee, että vuoteen 1970 mennessä maa- ja metsätaloudesta vapautuu arviolta 100000 henkilöä, jotka hakeutuvat muihin elinkeinoihin. Tämä lisää huomattavasti sitä taajamaelinkeinoihin suuntautuvaa painetta, jonka jo suuret ikäluokat muodostavat.

Elinkeinojen välinen työvoiman liikkuvuus on eräs taloudellisen kasvun ja täystyöllisyyden edellytys. Kehittyvässä yhteiskunnassa ei näin ollen työvoiman virtaamista maaseudulta ja maataloudesta ole suinkaan pidettävä onnettomuutena, vaikka se lyhyen ajanjakson puitteissa näyttäisikin vaikuttavan työllisyyteen vähentävästi. Päinvastoin tällaista siirtymistä olisi edistettävä paitsi lisäämällä työtilaisuuksien määrää sekundäärisissä ja tertiäärisissä elinkeinoissa myös tehostetulla ammattikoulutuksella. Ammatillisen valmennuksen riittämättömyydestä muodostuu nimittäin helposti työvoiman liikkuvuuden jarru. Kouluttamattomana nuori työvoima voi siirtyä perinteellisistä agraarisista elinkeinoista korkeintaan muihin maaseudun elinkeinoihin sellaisiin tehtäviin, jotka eivät vaadi ammattitaitoa. Tästä seuraisi, että he alusta alkaen olisivat alttiita työttömyydelle, ilmiö, jonka oireita maaseudulla voidaan jo nyt havaita nuorimmankin työvoiman keskuudessa, kuten edellä todettiin.

\section{Työvoiman työllistäminen}

Vaikka työvoima lisääntyykin lähivuosina kiistämättä poikkeuksellisen runsaasti, ei suurten ikäluokkien ongelma sittenkään liene oikea nimitys 1960-luvun työllisyyskysymykselle. Ensiksi voidaan nimittäin väittää, kuten edellä jo tuli mainituksi, että se tapa, jolla työllisyys yleensä hoidetaan, ratkaisee - tai jättää ratkaisematta - samalla myös suurten ikäluokkien ongelman. Jos työvoiman kysyntä on riittämätön, muodostuu työvoimareservi heikoimmasta työntekijäaineksesta, jossa on enemmän kouluttamatonta kuin koulutettua työvoimaa ja enemmän vanhoja kuin nuoria työntekijöitä. Toiseksi on muistettava, että työvoiman kasvu ei ole vain tarjontatekijä, vaan se itsessään lisää myös työvoiman kysyntää. Jokainen väestön lisäys vaikuttaa nimittäin sekä kulutukseen että tuotantoon. Esimerkkinä mainittakoon, että ei ole kauan siitä kun paljon puhutut suuret ikäluokkamme saivat aikaan hyvin huomattavan kansakoulujen rakennusohjelman, tällä hetkellä he ovat ammattikouluiässä ja vuosikymmenen loppupuolella he alkavat perustaa perheitä, mikä tietää asuntojen kysynnän lisääntymistä. Pitkäaikainen työttömyyden pelko on saatta- 
nut meidät tyystin unohtamaan sen, että työvoiman tarjonnan kasvun ei välttämättä tarvitse olla lisä vaikeuksiemme summaan, vaan se voi olla myös voima, jota ilman taloudellinen kasvu ja hyvinvoinnin lisääntyminen ei ole mahdollinen.

Ottaen huomioon kuluneen vuosikymmenen kokemukset näyttää siltä, että täystyöllisyyden saavuttaminen 1960luvulla on vaikea, mutta ei suinkaan ylivoimainen tehtävä. Tulevaa työllisyysongelmaa selvittelemään asetettu Talousohjelmakomitea on mietinnössään pyrkinyt löytämään sellaisen tuotantorakenteen, joka toteuttaisi täystyöllisyyden ja mahdollisimman nopean taloudellisen kasvun seuraavan kymmenen vuoden aikana. Komitea toteaa, että kun työvoima kasvaa 1960-luvun aikana noin $15 \%$, on kansantuotteen täystyöllisyyden saavuttamiseksi lisäännyttävä lähes $60 \%$ eli keskimäärin noin $4.3 \%$ vuodessa, jos edellytetään, että tuottavuuden kasvuprosentti on suunnilleen sama kuin 1950-luvulla eli noin $3 \%$ vuodessa. Työvoiman kysynnän (työpanoksen) pitäisi lisääntyä vuosina 1959-70 noin 24300 työvuodella eli $1.3 \%$ keskimäärin vuodessa. Todettakoon vertailun vuoksi, että vuosina 1948 -59 työpanos lisääntyi ainoastaan $0.8 \%$ vuotta kohden. Kuten aikaisemmin tuli mainituksi, työvoiman lisäyksen aiheuttama työllistämistehtävä keskittyy pääasiassa 1960-luvun alkuun. Vastatakseen työvoiman tarjontaa työpanoksen on lisäännyttävä esimerkiksi vuosina 1960 -62 keskimäärin noin 30000 työvuotta, mutta 1969-70 ainoastaan 18000 työvuotta vuosittain.

Koska maatalouden ja metsätalouden työpanokset pienenevät, ei työvoimaan tulevaa lisäystä voida sitoa maahan, vaan se on suunnattava sekundäärisiin ja tertiäärisiin elinkeinoihin: teollisuuteen, rakennustoimintaan ja palveluselinkeinoihin.

Teollisuutemme mahdollisuuksiin jatkuvasti lisätä työvoimaansa on usein suhtauduttu epäillen. Kuitenkin on niin, että teollistumisprosessi ei meillä ole vielä likimainkaan päätepisteessään, vaan teollisuuden työvoimaa voidaan vielä huomat- tavasti lisätä. Teollisuuden laajentumimiselle olisikin luotava edellytykset nyt, kun työvoiman kehitys on sille mahdollisimman edullinen. Työvoiman saanti ei kuitenkaan ole ainoa teollisuuden ekspansion edellytys, vaan kaikki riippuu siitä, voidaanko myös muuta tuotantovoimaa lisätä samassa mitassa. Talousohjelmakomitea on kiinnittänyt mietinnössään erityistä huomiota juuri teollisuuden investointeihin, jotka sen laatiman ennusteen mukaan kasvaisivat 1960-luvulla voimakkaammin kuin missään muussa elinkeinohaarassa. Vuodesta 1959 vuoteen 1970 teollisuuden bruttoinvestointien määrä kasvaisi nimittäin $99 \mathrm{mrd}$. markasta 188 mrd. markkaan vuoden 1959 hintatason mukaan laskettuna. Jos investointien kasvu tapahtuu komitean ennakoimalla tavalla, merkitsee se samalla huomattavaa investointirakenteen muutosta. Sen seurauksena teollisuuden investointien osuus kaikista investoinneista, joka vuonna 1959 oli $27 \%$, nousisi vuonna 1970 jo 34 \%:iin. Sanotunlainen investointien suuntaus on välttämätön täystyöllisyyteen pyrkivässä kansantaloudessa, sillä teollisuuden pääoman lisäyksellä on hyvin huomattava välillinen työllisyysvaikutus, joskin sen välitön vaikutus saattaa olla pienempi kuin samansuuruisella investoinnilla jossakin muussa elinkeinohaarassa.

Teollisuuden työllisyyden ennustetaan lisääntyvän 1960-luvun aikana keskimäärin noin 10000 työvuotta eli $2 \%$ vuosittain. Absoluuttisesti lisäys on suurempi kuin missään muussa elinkeinossa, mutta suhteellisesti kuitenkin pienempi kuin palveluselinkeinojen vastaava lisäys.

Väestön voimakas kasvu ja laajat investoinnit edellyttävät myös rakennustoiminnan työllisyyden lisääntymistä. Investointien aiheuttamasta rakennustarpeesta johtuen työpanoksen lisäys tulee huomattavan suureksi vuosikymmenen alkupuolella, mutta hidastuu sen loppupuolella. Sellaista työllisyysvaroin rahoitettujen töiden aiheuttamaa maa- ja vesirakennustoiminnan työllisyyden lisäystä, joka tapahtui 1950-luvun lopulla, tuskin alkaneella vuosikymmenellä esiintyy. 
Maa- ja vesirakennustoiminnan töitä voidaan nimittäin hyvin huomattavassa määrin koneistaa, joten tuottavuuden nousu pitänee työpanoksen muuttumattomana aina vuosikymmenen loppupuolelle saakka, jolloin se voi pienentyäkin.

Kaupan, liikenteen ja varsinaisten palvelusten yhäti lisääntyvä merkitys työtilaisuuksien tarjoajina usein unohdetaan. Asian luonteeseen kuuluu, että näiden palveluselinkeinojen osuus työpanoksesta jatkuvasti kasvaa. Kulutusrakenteen muutos ja muiden elinkeinojen työllisyyden tai tuottavuuden lisäyksen aiheuttama nettotuotoksen kasvu saavat nimittäin aikaan palvelusten lisääntyvää kysyntää, mikä johtaa työllisyyden lisäykseen, koska tuottavuus palveluselinkeinoissa voi nousta vain vähäisessä määrin. Samoin muiden elinkeinojen työvoiman lisäys luo työllisyyden kerrannaisvaikutuksen avulla uusia työtilaisuuksia palveluselinkeinoissa usein enemmän kuin siinä elinkeinossa, jossa työllisyyttä lisäävä investointi on suoritettu. Talousohjelmakomitea onkin arvioinut, että palveluselinkeinojen työpanokset kasvavat 1960-luvulla keskimäärin yli kaksi kertaa nopeammin kuin kokonaistyöpanos.

Työvoiman tarjonnan nopeasta lisääntymisestä huolimatta on täystyöllisyyden saavuttaminen 1960-luvulla täysin mahdollisuuksien rajoissa. Tehtävän onnistuminen edellyttää kuitenkin, että harjoitetaan taloudelliseen kasvuun ja täystyöllisyyteen johtavaa talouspolitiikkaa. Tällä keinolla vältetään uuden vuosikymmenen työttömyysongelman syntyminen. Saman ohjelman puitteissa voidaan ratkaista myös suurten ikäluokkien työllisyyskysymys edellyttäen, että nuorten työntekijäin ammatillisesta kasvatuksesta huolehditaan ja luodaan heille mahdollisuus tulla kil pailukykyisinä työmarkkinoille tässä teknillistyvässä ja teollistuvassa yhteiskunnassa. Lopuksi voidaan todeta, että kovin kaukana ei ole se aika, jolloin työmarkkinoihin liittyvät ongelmat saattavat olla kokonaan toisenlaatuisia kuin nykypäivinä. Näyttää nimittäin varsin ilmeiseltä, että 1960-luvun loppupuolella tai viimeistään 1970-luvun alussa on uhkaamassa työvoimapula. Tämä on syytä muistaa jo nyt, jolloin me vielä keskustelemme työvoiman ylitarjonnan mahdollisuudesta. 